\title{
Perubahan Beberapa Sifat Fisika Gambut Akibat Lamanya Penggunaan Lahan di Rawa Tripa
}

\author{
(The Change in Some Peat Physical Character due to the Length of Land Use in Rawa Tripa)
}

\author{
Silvia Anggita Devi ${ }^{1}$, Khairullah ${ }^{1}$, M. Rusli Alibasyah ${ }^{1 *}$ \\ ${ }^{1}$ Program Studi Ilmu Tanah, Fakultas Pertanian, Universitas Syiah Kuala
}

\begin{abstract}
Abstrak. Histosol merupakan tanah organik yang terbentuk dari kumpulan bahan-bahan organik seperti serasah tumbuhan yang terdekomposisi dalam jangka waktu yang lama. Di Aceh sendiri wilayah ekosistem rawa gambut yang telah dikonversi menjadi lahan pertanian dan perkebunan adalah wilayah barat mulai dari Kabupaten Aceh Jaya hingga Kabupaten Aceh Singkil. Penelitian ini bertujuan untuk melihat perubahan beberapa sifat fisika dan kimia gambut akibat lamanya penggunaan lahan di Rawa Tripa Kabupaten Nagan Raya.Hasil penelitian dan analisis pada perubahan sifat fisika gambut akibat lamanya penggunaan lahan menunjukan bahwa kadar air tertinggi tedapat pada sampel $\mathrm{U}_{0}$ (sub soil) yaitu $275,94 \%$ dan kadar air terendah pada sampel $\mathrm{U}_{3}$ (top soil) yaitu $81,16 \%$. Berat volume tertinggi terdapat pada sampel $\mathrm{U}_{3}$ (top soil) yaitu $0,90 \mathrm{~g} / \mathrm{cm}^{3}$ dan berat volume terendah pada sampel $\mathrm{U}_{0}$ (sub soil) yaitu $0,41 \mathrm{~g} / \mathrm{cm}^{3}$. Porositas tertinggi terdapat pada $\mathrm{U}_{0}$ (sub soil) yaitu $97,16 \%$ dan yang terendah terdapat pada $\mathrm{U}_{3}$ (top soil) yaitu 64,11\%. Hasil pengamatan lapangan pada kematangan gambut menunjukan bahwa gambut rawa tripa memiliki tingkat kematangan hemik dan saprik, kedalaman gambut yaitu dangkal sampai sangat dalam, subsidence terjadi akibat pengarih drainase dan warna gambut yaitu hitam kemerahan sampai coklat kehitaman.
\end{abstract}

Kata Kunci: Histosol, Sifat Fisika, Nagan Raya.

\begin{abstract}
Histosol is an organic soil formed from a collection of organic materials such as plant litter which was decomposed for a long time. In Aceh, the peat swamp ecosystem area that has been converted into agricultural land and plantations is in the west, starting from Aceh Jaya Regency to Aceh Singkil Regency. This study aims to look at the change in some physical and chemical properties of peat due to the length of land use in Tripa Swamp in Nagan Raya District. The results of the research and analysis on the change in the physical properties of peat due to the length of land use showed that the highest moisture content was found in samples of $\mathrm{U}_{0}$ ( $s u b$ soil) which was $275.94 \%$ and the lowest water content in $\mathrm{U}_{3}$ (top soil) sample of $81.16 \%$. The highest volume weight is found in the sample $\mathrm{U}_{3}$ (top soil) which is $0.90 \mathrm{~g} / \mathrm{cm} 3$ and the lowest volume weight in the sample $\mathrm{U}_{0}$ (sub soil) is $0.41 \mathrm{~g} / \mathrm{cm} 3$. The highest porosity is found in $\mathrm{U}_{0}$ (sub soil), namely $97.16 \%$ and the lowest is in $\mathrm{U}_{3}$ (top soil), which is $64.11 \%$. The results of field observations on peat maturity show that tripe swamp peat has a level of hemic and sapric maturity, peat depth that is shallow to very deep, subsidence occurs due to drainage and the color of peat is reddish black to blackish brown.
\end{abstract}

Keywords: Histosols, Physical Properties, Nagan Raya.

\section{PENDAHULUAN}

Histosol merupakan tanah organik yang terbentuk dari kumpulan bahan-bahan organik seperti serasah tumbuhan yang terdekomposisi dalam jangka waktu yang lama. Keadaan morfologi tanah gambut umumnya selalu jenuh air dan selalu terendam air kecuali setelah didrainase. Dapat dikatakan sebagai lahan gambut apabila memiliki kedalaman gambut lebihdari $50 \mathrm{~cm}$. Maka dengan demikian, lahan rawa yang memiliki kedalaman lebih dari 50 $\mathrm{cm}$ disebut lahan gambut.Proses terbentuknya tanah gambut disebut dengan proses geogenik sedangkan proses terbentuknya tanah mineral disebut dengan proses pedogenik (WidjajaAdhi, 1992; Riwandi, 2003; Hairiah et al., 2011). 
Pemanfaatan lahan gambut di Indonesia khususnya pada sektor pertanian dan perkebunan kelapa sawit sudah banyak dilakukan di Pulau Kalimantan, Provinsi Sumatera Selatan, Provinsi Riau dan Provinsi Aceh. Provinsi Aceh sendiri wilayah ekosistem rawa gambut yang telah dikonversi menjadi lahan pertanian dan perkebunan adalah wilayah barat mulai dari Kabupaten Aceh Jaya hingga Kabupaten Aceh Singkil.Sebelum di alih fungsikan menjadi lahan pertanian dan perkebunan lahan pada areal ini merupakan hutan rawa gambut yang mempunyai keanekaragaman hayati yang tinggi dan mengandung karbon (C) yang cukup tinggi karena sebagian dari rawa ini terdapat bahan gambut yang banyak mengandung unsur karbon (Sufardi et al., 2013).

Berdasarkan hasil penelitian dan informasi di lapangan yang dilakukan Baidil (2016) pada gambut Rawa Tripa proses pembukaan lahan kelapa sawit sebelum dilakukan penanaman terlebih dahulu lahan dikeringkan dengan membuat drainase, yang berdampak pada penyusutan permukaan (subsidence). Lahan gambut Rawa Tripa sering terjadi banjir karena tingginya curah hujan sehingga menyebabkan perubahan tingkat kematangan gambut. Berdasarkan uraian tersebut maka kiranya perlu dilakukan penelitian tentang perubahan beberapa sifat fisika dan kimia gambut akibat lamaanya penggunaan lahan di Rawa Tripa Kabupaten Nagan Raya.

\section{METODE PENELITIAN}

Penelitian ini dilaksanakan di Laboratorium Fisika dan Kimia tanah Fakultas Pertanian Universitas Syiah Kuala dengan wilayah kajian Kabupaten Nagan Raya.

\section{MATERI DAN METODE}

Alat yang digunakan dalam penelitian antara yaitu ring sampel, bor gambut, buku Munsell Soil Color Chart, meteran, parang, GPS, cangkul, timbangan, kamera, kantung plastik transparan, kertas label, serta alat-alat tulis untuk menganalisis sifat fisika dan sifat kimia tanah di Laboratorium. Sedangkan bahan yang digunakan dalam penelitian ini diantaranya contoh tanah utuh, tanah komposit dan peta kerja.

Metode yang digunakan pada penelitan ini yaitu metode metode deskriptif dengan teknik survei, sedangkan analisis data menggunakan analisis Laboratorium. Tahapan penelitian mencakup penentuan titik pengambilan sampel, pengamatan lapangan, dan analisis di Laboratorium. Urutan pelaksanaan penelitian dapat dilihat pada Gambar 1. 


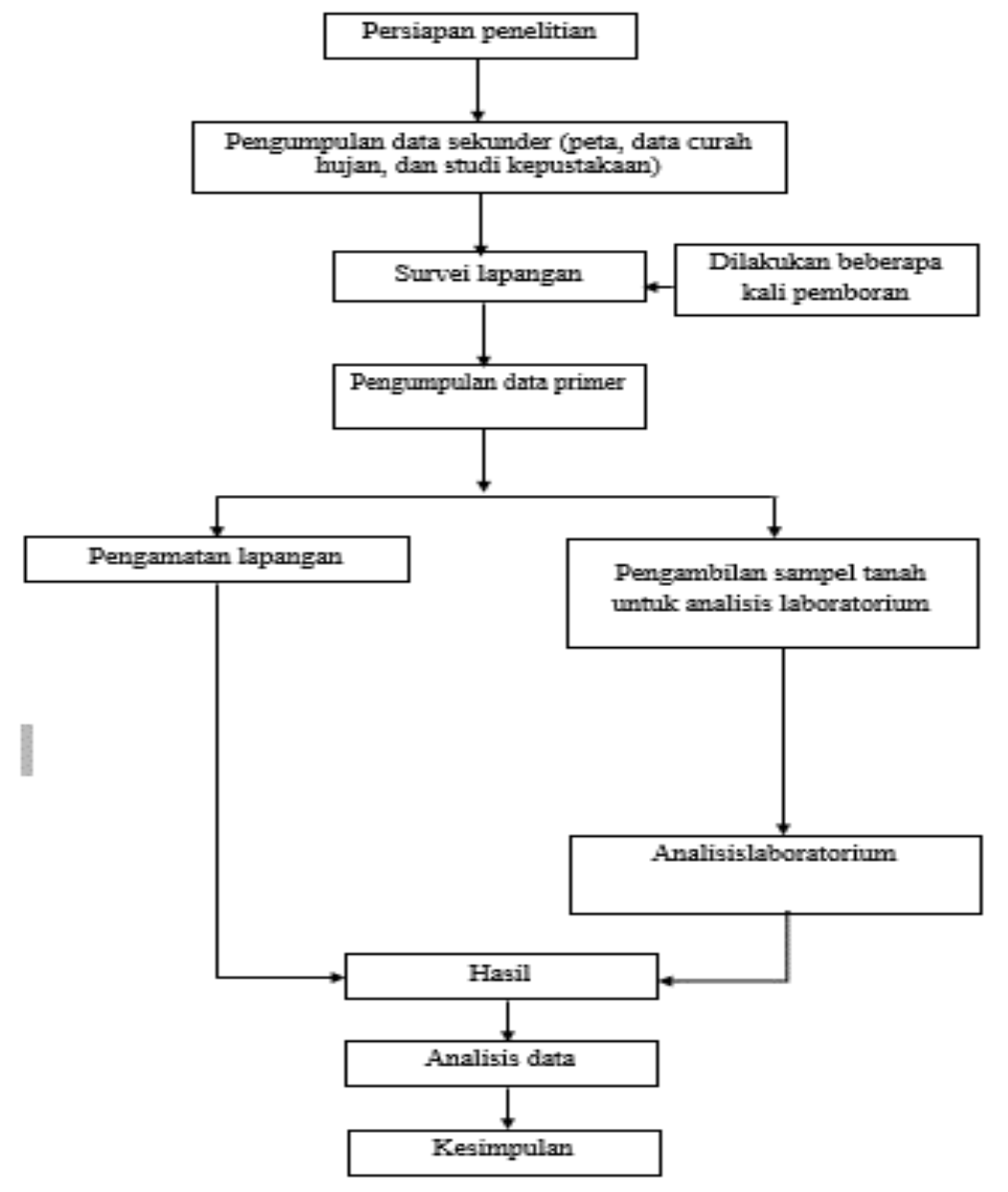

Gambar 1. Diagram Alir Penelitian

\section{Pelaksanaan Penelitian}

\section{Penentuan Titik Pengambilan Sampel}

Penentuan titik sampel dilakukan berdasarkan peta kerja dan disesuaikan dengan keadaan di lapangan. Pengambilan sampel dilakukan pada kebun kelapa sawit milik rakyat berdasarkan umur tanaman kelapa sawit: 1 - 3 tahun, 3 - 6 tahun, dan 6 - 9 tahun sedangkan untuk perbandingan dengan gambut yang belum ditanami juga dilakukan pengambilan sampel di luar areal atau pada lahan yang tidak ditanami tanaman kelapa sawit. Pengambilan sampel tanah dilakukan dua jenis, yaitu sampel tanah utuh dan sampel tanah tidak utuh. Pengambilan sampel tanah tidak utuh dengan menggunakan bor gambut pada beberapa titik kemudian dikompositkan. Sedangkan sampel utuh dilakukan dengan menggunakan ring sample. Pengambilan sampel dilakukan dengan menggunakan metode proposive random sampling, pada setiap satuan lahan di lakukan pengambilan 4 titik pengamatan dan pada setiap titik dilakukan pengambilan sampel berdasarkan kedalaman yaitu $0-20 \mathrm{~cm}$ dan $20-40 \mathrm{~cm}$. Untuk lebih jelasnya dapat dilihat pada Tabel 1 . 
Tabel 1. Pengambilan titik sampel

\begin{tabular}{cccccc}
\hline No & $\begin{array}{c}\text { Umur Kelapa Sawit } \\
\text { (Tahun) }\end{array}$ & Luas (ha) & \multicolumn{2}{c}{ Kedalaman Sampel (cm) } & \multirow{2}{*}{$\begin{array}{c}\text { Jumlah } \\
\text { Sampel }\end{array}$} \\
\cline { 4 - 5 } & & & $0-20$ & $20-40$ & \\
\hline 1. & Hutan Gambut & 1,73 & 2 & 2 & 4 \\
2. & $1-3$ & 27,35 & 4 & 4 & 8 \\
3. & $3-6$ & 17,75 & 4 & 4 & 8 \\
4. & $6-9$ & 11,56 & 4 & 4 & 8 \\
\hline & Total & 58,39 & 14 & 14 & 28 \\
\hline
\end{tabular}

Keterangan:

$\mathrm{U}_{0}=$ Tanah yang tidak dibudidaya (hutan)

$\mathrm{U}_{1}=$ Umur tanaman kelapa sawit $1-3$ tahun

$\mathrm{U}_{2}=$ Umur tanaman kelapa sawit 3-6 tahun

$\mathrm{U}_{3}=$ Umur tanaman kelapa sawit 6-9 tahun

\section{Pengamatan Lapangan}

Pengamatan lapangan akan dilakukan pada lahan-lahan yang sudah ditanami kelapa sawit milik rakyat, kemudian diidentifikasikan faktor-faktor morfologi yang menentukan kualitas lahan untuk tanaman kelapa sawit yang ditanam di lahan gambut. Adapun parameter morfologi yang akan dilakukan dalam observasi di lapangan dapat dilihat pada Tabel 2.

Tabel 2. Sifat-sifat morfologi lahan gambut

\begin{tabular}{lll}
\hline No & Sifat Morfologi Yang Diamati & Alat atau metode pengamatan \\
\hline 1. & Tingkat kematangan gambut & Diremas/diperas dengan tangan \\
2. & Kedalaman gambut & Bor gambut/bor kedalaman efektif \\
3. & Subsidence & Dilihat melalui berat volume \\
4. & Warna Tanah & Soil Munsell Color chart \\
\hline
\end{tabular}

\section{Analisis di Laboratorium}

pengamatan di laboratorium akan dilakukan setelah pengambilam sampel tanah di lapangan. Adapun analisis yang dilakukan di laboratorium adalah analisis fisika tanah dan kimia tanah. Parameter yang akan dianalisis dapat dilihat pada Tabel 3.

Tabel 3. Komponen, parameter dan metode analisis laboratorium

\begin{tabular}{|c|c|c|c|c|}
\hline No. & Komponen & Parameter & Satuan & Metode Analisis \\
\hline \multirow{3}{*}{1} & \multirow{3}{*}{ Sifat Fisika } & Berat volume tanah & $\mathrm{g} \mathrm{cm}^{-3}$ & Ring Sampel (Core) \\
\hline & & Porositas total & $\%$ & Gravimetri \\
\hline & & Kadar Air & $\%$ volume & Kering oven $\left(105^{\circ} \mathrm{C}\right)$ \\
\hline \multirow{4}{*}{2} & \multirow{4}{*}{ Sifat Kimia } & $\mathrm{pH}$ & & Elektrometrik \\
\hline & & KTK & $\mathrm{Cmol} \mathrm{kg}^{-1}$ & Ektraksi $1 N \mathrm{NH} 4 \mathrm{O}$ Ac pH7 \\
\hline & & C-organik & $(\%)$ & Walkley \& Black \\
\hline & & N-total & $(\%)$ & Kjeldahl \\
\hline
\end{tabular}

Perubahan Beberapa Sifat Fisika Dan Kimia Gambut Akibat Lamanya Penggunaan Lahan Di Rawa Tripa Kabupaten Nagan Raya 


\section{HASIL DAN PEMBAHASAN}

Sifat fisika tanah gambut yang diambil di lokasi penelitian dan dianalisis di Laboratorium Fisika tanah dan lingkungan yaitu kadar air, berat volume, dan porositas, dapat dilihat pada Tabel 4.

Tabel 4. Hasil analisis fisika tanah gambut Rawa Tripa

\begin{tabular}{|c|c|c|c|c|}
\hline \multirow[t]{2}{*}{ No } & \multirow{2}{*}{$\begin{array}{l}\text { Umur Gambut } \\
\text { (Tahun) }\end{array}$} & \multicolumn{3}{|c|}{ Parameter Fisika Tanah } \\
\hline & & $\begin{array}{c}\text { Kadar Air } \\
(\%)\end{array}$ & $\begin{array}{l}\text { Berat Volume } \\
\left(\mathrm{g} / \mathrm{cm}^{3}\right)\end{array}$ & Porositas $(\%)$ \\
\hline 1 & Hutan (Top $\mathrm{U}_{0}$ ) & 271,75 (tinggi) & 0,43 (rendah) & 95,21 (tinggi) \\
\hline 2 & Hutan $\left(\operatorname{Sub} \mathrm{U}_{0}\right)$ & 275,94 (tinggi) & 0,41 (rendah) & 97,16 (tinggi) \\
\hline 3 & 1 - $3\left(\right.$ Top $\left.U_{1}\right)$ & 144,50 (tinggi) & 0,50 (rendah) & 86,58 (tinggi) \\
\hline 4 & $1-3\left(\mathrm{Sub} \mathrm{U}_{1}\right)$ & 194,12 (tinggi) & 0,47 (rendah) & 93,34 (tinggi) \\
\hline 5 & $3-6\left(\right.$ Top $\left.U_{2}\right)$ & 96,08 (rendah) & 0,71 (rendah) & 81,84 (tinggi) \\
\hline 6 & $3-6\left(\mathrm{Sub} \mathrm{U}_{2}\right)$ & 104,08 (tinggi) & 0,64 (rendah) & 82,28 (tinggi) \\
\hline 7 & $6-9\left(\right.$ Top $\left.U_{3}\right)$ & 81,16 (rendah) & 0,90 (sedang) & 64,11 (sedang) \\
\hline 8 & $6-9\left(\mathrm{Sub} \mathrm{U}_{3}\right)$ & 86,92 (rendah) & 0,72 (rendah) & 70,16 (sedang) \\
\hline
\end{tabular}

Sumber: data hasil analisis Fisika Tanah (2018)

\section{Kadar Air}

Berdasarkan hasil analisis kadar air, diketahui bahwa nilai kadar air yang bervariasi antara 81,16 - 275,94\%, sampel $\mathrm{U}_{0}$ pada sub soil memiliki kadar air yang lebih tinggi yaitu $275,94 \%$ dibandingkan dengan sampel tanah $\mathrm{U}_{1}, \mathrm{U}_{2}$ dan $\mathrm{U}_{3}$. Hal ini dikarenakan lamanya budidaya tanaman dan pengeringan lahan gambut saat dilakukan budidaya dan terlebih lagi sawit merupakan tanaman yang boros air. Kadar air lahan gambut semakin berkurang apabila drainase yang dilakukan terlalu berlebihan. Untuk lahan gambut pada lokasi penelitan di Desa Lueng Keubeu Jagat Kecamatan Tripa Makmur Kabupaten Nagan Raya memiliki kadar air yang semakin menurun pada tingkat kematangan yang lebih lanjut. Hal ini di karenakan semakin matang lahan gambut maka berat volume meningkat, pori - pori tanah akan semakin baik sehingga kadar air yang ada semakin berkurang.

\section{Berat Volume}

Berdasarkan hasil penelitian di Laboratorium berat volume tanah gambut di lokasi penelitian berkisar antara $0,41-0,90 \mathrm{gr} / \mathrm{cm}^{3}$. Berat volume tanah tertinggi berada pada lokasi sampel top soil $U_{3}$ yaitu pada lahan gambut yang dibudidayakan selama 9 tahun. Sedangkan berat volume terendah di subsoil $\mathrm{U}_{0}$ yaitu pada tanah yang belum dibudidayakan. Hal ini dikarenakan tanah yang telah lama dibudidaya dengan kelapa sawit telah mengalami penurunan permukaan dan pemadatan tanah yang sangat berpengaruh terhadap berat volume tanah. Namun pada tanah hutan gambut $\mathrm{U}_{0}$ yang belum dibudidaya memiliki berat volume paling rendah diantara lahan yang sudah dibudidaya karena belum mengalami penurunan permukaan dan pemadatan tanah.

\section{Porositas}

Berdasarkan hasil analisis di Laboratorium, dapat dilihat bahwa porositas mengalami korelasi dengan lamanya penggunaan, dimana semakin lama semakin menurun porositasnya yaitu $64,11-97,16 \%$. Sifat tanah gambut memiliki berat volume rendah dan porositas yang tinggi. Semakin lama penggunaan lahan gambut maka semakin menurun nilai porositasnya,

Perubahan Beberapa Sifat Fisika Dan Kimia Gambut Akibat Lamanya Penggunaan Lahan Di Rawa Tripa Kabupaten Nagan Raya 
dikarenakan dekomposisi yang lebih lanjut maka lahan gambut semakin matang dan berkurangnya pori-pori yang ada di dalam tanah sehingga porositas semakin berkurang.

\section{Tingkat Kematangan Gambut}

Berdasarkan hasil pengamatan di lapangan, didapatkan bahwa tingkat kematangan gambut pada areal penelitian memiliki korelasi positif terhadap lamanya penggunaan dan tingkat kematangan gambut. Pada lahan yang belum di tanami (hutan gambut) dan yang ditanami tanaman kelapa sawit umur 1 - 3 tahun memiliki tingkat kematangan gambut hemik, pada lahan yang ditanami tanaman kelapa sawit umur $3-6$ tahun dan $6-9$ tahun memiliki tingkat kematangan gambut saprik. Dapat dilihat pada Tabel 5.

Tabel 5. Tingkat Kematangan Gambut Rawa Tripa

\begin{tabular}{cc}
\hline Titik & Tingkat Kematangan \\
\hline Top $U_{0}$ & Saprik \\
Sub $U_{0}$ & Saprik \\
Top U & Saprik \\
Sub U & Saprik \\
Top U & Saprik \\
Sub $U_{2}$ & Saprik \\
Top U & Saprik \\
Sub $U_{3}$ & Saprik \\
\hline
\end{tabular}

\section{Kedalaman Gambut}

Berdasarkan hasil pengamatan di lapangan, didapatkan bahwa kedalaman gambut berada pada kriteria sangat dangkal hingga sangat dalam. Kedalaman gambut di lapangan sangat berkaitan dengan tingkat kematangan gambut dan drainase yang ada, semakin matang gambut maka semakin dangkal pula permukaan gambut. Kedalaman gambut juga berkaitan pada sistem drainase yang ada pada lahan kelapa sawit, apabila laju drainase cepat maka terjadi subsidence (penurunan permukan) yang mempengaruhi tingkat kedalaman gambut. Dapat dilihat pada Tabel 6.

Tabel 6. Kedalaman gambut Rawa Tripa

\begin{tabular}{ccc}
\hline Titik sampel & Kedalaman gambut $(\mathrm{cm})$ & Kriteria \\
\hline $\mathrm{U}_{0}$ & 300 & Sangat dalam \\
$\mathrm{U}_{1}$ & 200 & Sangat dalam \\
$\mathrm{U}_{2}$ & 150 & Sangat dalam \\
$\mathrm{U}_{3}$ & 50 & Sangat dangkal \\
\hline
\end{tabular}

\section{Subsidence}

Berdasarkan hasil pengamatan dilapangan, didapatkan bahwa subsidence terjadi karena adanya pengaruh drainase pada setiap lahan kelapa sawit. Selain karena drainase, akar yang muncul di permukaan juga menjadi tanda bahwa pada lahan yang di teliti mengalami penurunan permukaan. Subsidence juga terjadi karena penyusutan berat volume akibat adanya proses dekomposisi. Semakin lama penggunaan lahan kelapa sawit maka nilai berat volume nya semakin bertambah, hal ini dapat dilihat pada hasil analisis laboratorium yaitu pada $\mathrm{U}_{3}$ berat volume semakin bertambah porositas juga semakin rendah. Pemadatan yang terjadi pada lahan tersebut dikarenakan bahan organik pada gambut sudah melapuk dan menjadi lebih

Perubahan Beberapa Sifat Fisika Dan Kimia Gambut Akibat Lamanya Penggunaan Lahan Di Rawa Tripa Kabupaten Nagan Raya 
halus sehingga pori-pori yang ada pada gambut menjadi lebih kecil. Peningkatan dari hasil berat volume ini lah yang menjadi dasar untuk mengetahui seberapa besar penurunan permukaan pada lahan gambut.

\section{Warna Gambut}

Berdasarkan pengamatan dilapangan dengan Munsell Soil Color Chart warna tanah gambut pada lapisan topsoil dan subsoil memiliki warna yang berbeda, lapisan paling atas memiliki warna lebih gelap dari pada lapisan bagian bawahnya. Pada $\mathrm{U}_{0}$ (hutan gambut) warna gambut pada kedalaman $0-20 \mathrm{~cm}$ adalah $10 \mathrm{R} \mathrm{2.5/1}$ (hitam kemerahan) dan pada kedalaman $20-40 \mathrm{~cm}$ adalah 10 YR 2/1 (coklat kehitaman). Pada $\mathrm{U}_{1}, \mathrm{U}_{2}$, dan $\mathrm{U}_{3}$ pada kedalaman $0-20 \mathrm{~cm}$ memiliki warna 5 YR 3/2 (coklat kemerahan gelap) dan pada kedalama $20-40 \mathrm{~cm}$ memiliki warna 10 YR 2/1 (coklat kehitaman) dapat dilihat pada Tabel 7.

Tabel 7. Warna Gambut Rawa Tripa

\begin{tabular}{|c|c|c|c|}
\hline Umur tanaman (tahun) & Kedalaman $(\mathrm{cm})$ & Titik & Warna Tanah \\
\hline Top $\mathrm{U}_{0}$ & $0-20$ & $\begin{array}{l}\text { I } \\
\text { II }\end{array}$ & $\begin{array}{l}10 \mathrm{R} 2,5 / 1 \\
10 \mathrm{R} 2,5 / 1\end{array}$ \\
\hline Sub $U_{0}$ & $20-40$ & $\begin{array}{l}\text { I } \\
\text { II }\end{array}$ & $\begin{array}{l}10 \mathrm{YR} 2 / 1 \\
10 \mathrm{YR} 2 / 1\end{array}$ \\
\hline $\begin{array}{l}\text { Top } U_{1} \\
(1-3)\end{array}$ & $0-20$ & $\begin{array}{l}\text { I } \\
\text { II } \\
\text { III } \\
\text { IV }\end{array}$ & $\begin{array}{l}5 \mathrm{YR} 3 / 2 \\
5 \mathrm{YR} 3 / 2 \\
5 \mathrm{YR} 3 / 2 \\
5 \mathrm{YR} 3 / 2\end{array}$ \\
\hline $\begin{array}{l}\text { Sub } U_{1} \\
(1-3)\end{array}$ & $20-40$ & $\begin{array}{l}\text { I } \\
\text { II } \\
\text { III } \\
\text { IV }\end{array}$ & $\begin{array}{l}10 \mathrm{YR} 2 / 1 \\
10 \mathrm{YR} 2 / 1 \\
10 \mathrm{YR} 2 / 1 \\
10 \mathrm{YR} 2 / 1\end{array}$ \\
\hline $\begin{array}{l}\text { Top } U_{2} \\
(3-6)\end{array}$ & $0-20$ & $\begin{array}{l}\text { I } \\
\text { II } \\
\text { III } \\
\text { IV }\end{array}$ & $\begin{array}{l}5 \mathrm{YR} 3 / 2 \\
5 \mathrm{YR} 3 / 2 \\
5 \mathrm{YR} 3 / 2 \\
5 \mathrm{YR} 3 / 2\end{array}$ \\
\hline $\begin{array}{c}{\text { Sub } U_{2}} \\
(3-6)\end{array}$ & $20-40$ & $\begin{array}{l}\text { I } \\
\text { II } \\
\text { III } \\
\text { IV }\end{array}$ & $\begin{array}{l}10 \mathrm{YR} 2 / 1 \\
10 \mathrm{YR} 2 / 1 \\
10 \mathrm{YR} 2 / 1 \\
10 \mathrm{YR} 2 / 1\end{array}$ \\
\hline $\begin{array}{c}\text { Top } U_{3} \\
(6-9)\end{array}$ & $0-20$ & $\begin{array}{l}\text { I } \\
\text { II } \\
\text { III } \\
\text { IV }\end{array}$ & $\begin{array}{l}5 \text { YR } 3 / 2 \\
5 \text { YR } 3 / 2 \\
5 \text { YR } 3 / 2 \\
5 \text { YR } 3 / 2\end{array}$ \\
\hline $\begin{array}{c}\mathrm{Sub}_{3} \\
(6-9)\end{array}$ & $20-40$ & $\begin{array}{l}\text { I } \\
\text { II } \\
\text { III } \\
\text { IV }\end{array}$ & $\begin{array}{l}10 \mathrm{YR} 2 / 1 \\
10 \mathrm{YR} 2 / 1 \\
10 \mathrm{YR} 2 / 1 \\
10 \mathrm{YR} 2 / 1\end{array}$ \\
\hline
\end{tabular}

Perubahan Beberapa Sifat Fisika Dan Kimia Gambut Akibat Lamanya Penggunaan Lahan Di Rawa Tripa Kabupaten Nagan Raya 


\section{Sifat Kimia Gambut Rawa Tripa}

Sifat kimia tanah gambut yang dianalisis di Laboratorium Penelitian Tanah dan Tanaman tanah dan lingkungan yaitu pH, C-organik, N-total dan Kapasitas Tukar Kation (KTK) dapat dilihat pada Tabel 8.

Tabel 8 . Hasil analisis Kimia Tanah Gambut Rawa Tripa

\begin{tabular}{cccccc}
\hline No & Umur & \multicolumn{4}{c}{ Parameter Kimia Tanah } \\
\cline { 3 - 6 } & $\begin{array}{c}\text { Tanaman } \\
(\text { Tahun})\end{array}$ & $\mathrm{pH}$ & $\begin{array}{c}\text { C-organik } \\
(\%)\end{array}$ & $\begin{array}{c}\text { N-Total } \\
(\%)\end{array}$ & Kapasitas Tukar Kation \\
\hline 1 & Hutan $\left(\mathrm{U}_{0}\right)$ & $4,37(\mathrm{sr})$ & $19,72(\mathrm{st})$ & $0,92(\mathrm{st})$ & $46,00(\mathrm{st})$ \\
2 & $1-3\left(\mathrm{U}_{1}\right)$ & $4,76(\mathrm{r})$ & $12,84(\mathrm{st})$ & $0,45(\mathrm{~s})$ & $38,80(\mathrm{t})$ \\
3 & $3-6\left(\mathrm{U}_{2}\right)$ & $4,35(\mathrm{sr})$ & $16,15(\mathrm{st})$ & $0,59(\mathrm{t})$ & $35,60(\mathrm{t})$ \\
4 & $6-9\left(\mathrm{U}_{3}\right)$ & $5,17(\mathrm{r})$ & $11,24(\mathrm{st})$ & $0,43(\mathrm{~s})$ & $38,00(\mathrm{t})$ \\
\hline
\end{tabular}

Sumber: Hasil analisis kimia tanah laboratorium penelitian tanah dan tanaman

Keterangan :

st : sangat tinggi $\quad \mathrm{s}$ : sedang

$\mathrm{t}$ : tinggi $\quad \mathrm{sr}:$ sangat rendah

\section{pH Tanah Gambut}

Berdasarkan hasil analisis $\mathrm{pH}$ tanah gambut dari empat sampel tanah gambut di lahan yang berbeda, menunjukkan bahwa nilai $\mathrm{pH}$ berada pada kriteria sangat masam sampai dengan masam. Nilai $\mathrm{pH}$ tanah tertinggi diperoleh dari tanah $\mathrm{U}_{3}$ (umur tanaman $6-9$ tahun) yaitu 5,17 (masam). Sedangkan nilai $\mathrm{pH}$ tanah terendah diperoleh dari lahan $\mathrm{U}_{2}$ (umur tanaman $3-6$ tahun) yaitu 4,35 (sangat masam). Hal ini menunjukan bahwa kondisi pH pada lahan $\mathrm{U}_{2}$ yang rendah terjadi karena pada lahan tersebut sering mengalami penggenangan.

\section{C-Organik}

Hasil analisis kandungan C-organik dari empat tipe penggunaan lahan yang berbeda, menunjukkan bahwa nilai C-organik berada pada kriteria sangat tinggi. Nilai C-organik tertinggi diperoleh dari $\mathrm{U}_{0}$ (lahan hutan) yaitu $19.72 \%$. Sedangkan nilai C-organik nilai yang rendah diperoleh dari lahan $\mathrm{U}_{3}$ yaitu 11.24 (rendah).

\section{N-total}

Hasil analisis kandungan $\mathrm{N}$-total dari empat tipe lahan pada perbedaan umur budidaya kelapa sawit rakyat, menunjukkan bahwa nilai $\mathrm{N}$-total berada pada kriteria sedang sampai dengan sangat tinggi. Nilai $\mathrm{N}$-total tertinggi diperoleh dari lahan hutan gambut $\left(\mathrm{U}_{0}\right)$ yaitu $0.92 \%$ (sangat tinggi). Sedangkan nilai $\mathrm{N}$-Total terendah diperoleh dari lahan $\mathrm{U}_{3}$ yaitu $0.43 \%$ (sedang).

\section{Rasio C/N Gambut}

Berdasarkan hasil perhitungan $\mathrm{C}$-organik dan $\mathrm{N}$-total maka di dapat hasil rasio $\mathrm{C} / \mathrm{N}$ gambut yang berbeda, $\mathrm{C} / \mathrm{N}$ gambut berada pada kriteria tinggi sampai dengan sangat tinggi. Nilai $\mathrm{C} / \mathrm{N}$ yang tertinggi terdapat pada lahan $\mathrm{U}_{1}$ yaitu 28.53 (sangat tinggi). Sedangkan nilai $\mathrm{C} / \mathrm{N}$ yang terendah terdapat pada lahan $\mathrm{U}_{0}$ yaitu 21.43 (tinggi). Pada lahan $\mathrm{U}_{0}$ (hutan gambut)

Perubahan Beberapa Sifat Fisika Dan Kimia Gambut Akibat Lamanya Penggunaan Lahan Di Rawa Tripa Kabupaten Nagan Raya 
memiliki nilai $\mathrm{C} / \mathrm{N}$ yang lebih rendah dari pada $\mathrm{U}_{1}$ dikarenakan pada lahan tersebut terpengaruh oleh drainase yang menyebabkan gambut menjadi keadaan aerob sehingga dekomposisi terjadi lebih cepat dapat dilihat pada Tabel 9.

Tabel 9. Hasil Rasio C/N Gambut Rawa Tripa

\begin{tabular}{ccccc}
\hline No & $\begin{array}{c}\text { Umur Tanaman } \\
\text { (Tahun) }\end{array}$ & $\begin{array}{c}\text { C-Organik } \\
(\%)\end{array}$ & $\begin{array}{c}\text { N-Total } \\
(\%)\end{array}$ & C/N \\
\hline 1 & Hutan $\left(\mathrm{U}_{0}\right)$ & 19,72 & 0,92 & 21,43 \\
2 & $1-3\left(\mathrm{U}_{1}\right)$ & 12,84 & 0,45 & 28,53 \\
3 & $3-6\left(\mathrm{U}_{2}\right)$ & 16,15 & 0,59 & 27,37 \\
4 & $6-9\left(\mathrm{U}_{3}\right)$ & 11,24 & 0,43 & 26,14 \\
\hline
\end{tabular}

Sumber: Hasil analisis kimia tanah laboratorium kimia tanah dan tanaman

\section{Kapasitas Tukar Kation}

Hasil analisis kandungan KTK dari empat tipe lahan pada perbedaan umur budidaya kelapa sawit rakyat, menunjukkan bahwa semua nilai KTK berada pada kriteria tinggi sampai sangat tinggi. Nilai KTK tertinggi diperoleh dari lahan hutan gambut $\mathrm{U}_{0}$ yaitu $46.00 \mathrm{me} / 100 \mathrm{~g}$ (sangat tinggi). Sedangkan nilai KTK terendah diperoleh dari lahan kelapa sawit dengan umur tanaman $3-6$ tahun $\mathrm{U}_{2}$ yaitu $35.60 \mathrm{me} / 100 \mathrm{~g}$ (sedang). Tingginya nilai KTK pada penggunaan lahan hutan gambut $\left(\mathrm{U}_{0}\right)$ disebabkan oleh adanya dekomposisi dari bahan organik yang menghasilkan koloid humus sehingga nilai kapasitas tukar kation menjadi sangat tinggi. Nilai KTK yang masih dalam kategori sangat tinggi diduga karena kondisi $\mathrm{pH}$ tanah yang masih tergolong sangat asam.

\section{Produksi Kelapa Sawit}

Lahan gambut merupakan lahan yang potensial untuk tanaman kelapa sawit. Tingkat produksi pada lahan gambut juga tidak berbeda jauh dengan tanah mineral lainnya. Pada tanaman kelapa sawit yang berusia $1-3$ tahun $\left(\mathrm{U}_{1}\right)$ belum berproduksi. Tanaman yang berusia $3-6$ tahun $\left(\mathrm{U}_{2}\right)$ sudah berproduksi tetapi belum maksimal, tanaman sawit yang berusia $6-9$ tahun $\left(\mathrm{U}_{3}\right)$ produksinya sudah maksimal. Hasil data yang didapat dari wawancara dengan petani di lapangan produksi tanaman kelapa sawit rakyat pada lahan gambut di Rawa Tripa 3 - 6 tahun $\left(U_{2}\right)$ memiliki hasil produksi sebanyak 2 ton/ha, namun pada tanaman kelapa sawit yang berumur 3 tahun masih memiliki buah pasir dan yang berproduksi adalah tanaman kelapa sawit yang berumur 4 tahun. Luas lahan kelapa sawit yang berusia $3-6$ tahun $\left(\mathrm{U}_{2}\right)$ adalah 17,75 ha jadi dalam sekali panen didapatkan hasil sebesar 35,5 ton. Tanaman kelapa sawit yang berusia $6-9$ tahun $\left(\mathrm{U}_{3}\right)$ memiliki hasil produksi mencapai 5 ton/ha dalam sebulan dilakukan pemanenan sebanyak dua kali jadi hasil produksi kelapa sawit pada lahan tersebut mencapai 10 ton/ha. Luas lahan kelapa sawit yang berusia 6 - 9 tahun $\left(\mathrm{U}_{3}\right)$ adalah 11,56 ha jadi dalam sekali panen masyarakat mendapatkan hasil sebesar 115,6 ton.

\section{SIMPULAN DAN SARAN}

Hasil analisis kadar air yang tertinggi terdapat pada Sub Uoyaitu 275,94dan yang terendah terdapat pada Top $\mathrm{U}_{3}$ yaitu 81,16 , pada berat volume nilai tertinggi terdapat pada Top Usyaitu 0,90dan yang terendah terdapat pada Sub Uoyaitu 0,41, pada porositas nilai yang

Perubahan Beberapa Sifat Fisika Dan Kimia Gambut Akibat Lamanya Penggunaan Lahan Di Rawa Tripa Kabupaten Nagan Raya 
tertinggi terdapat pada Sub U0yaitu 97,16dan yang terendah tedapapat pada Top U 3 yaitu 64,11.Perlu dilakukan pengkajian lebih lanjut terhadap sifat biologi tanah sebagai bahan acuan yang lebih lengkap sehingga perencanaan pengolahan lahan dan konservasi tanah dan air dapat berjalan dengan baik.

\section{DAFTAR PUSTAKA}

Widjaja-Adhi, I P.G. 1992. Lahan Rawa dan Permasalahannya di Indonesia.

Riwandi. 2003. Indikat or Stabilitas Gambut Berdasarkan Analisis Kehilangan Karbon Organik, Sifat Fisikokimia dan Komposisi Bahan Gambut. Jurnal Penelitian UNIB. Bengkulu.

Hairiah K, Ekadinata A, Sari RR, Rahayu S. 2011. Pengukuran cadangan karbon dari tingkat lahan ke bentang lahan. Edisi 2. World Agroforestry Centre, ICRAF South East Asia dan Universitas Brawijaya.Malang. Indonesia.

Sufardi, Z. Thomy, H. Basri, A. Anhar, Fajri, A. Halim. 2013. Scientific studies for the rehabilitation and management of the Tripa peat swamp forest. Unpublished field report.

Baidil, 2017. Karakteristik gambut setelah 10 tahun digunakan sebagai kebun kelapa sawit rakyat di areal Rawa Tripa Kabupaten Nagam Raya. Tesis. Program Studi Magister Konservasi Sumber Daya Lahan Program Pasca Sarjana Universitas Syiah Kuala. 